\title{
CLCN6 Gene
}

National Cancer Institute

\section{Source}

National Cancer Institute. CLCN6 Gene. NCI Thesaurus. Code C111952.

This gene plays a role in chloride ion transport. 